\title{
Variations of construction cost associated to leaf area renewal in saplings of two co-occurring temperate tree species (Acer platanoides L. and Fraxinus excelsior L.) along a light gradient
}

\author{
Sandrine BARTHOD ${ }^{\mathrm{a}}$, Daniel EPRON ${ }^{\mathrm{b} *}$ \\ ${ }^{a}$ Université de Franche-Comté, Laboratoire de Biologie Environnemental, EA 3184 USC INRA, Pôle universitaire, \\ BP 71427, 25211 Montbéliard Cedex, France \\ b Université Henri Poincaré - Nancy 1, UMR 1137 INRA - UHP Écologie et Écophysiologie Forestières, \\ BP 239, 54506 Vandœuvre Cedex, France
}

(Received 15 June 2004; accepted 14 January 2005)

\begin{abstract}
The yearly renewal of leaves and their holding organs (the leafy shoot) represent an energetic cost for saplings. The contribution of both biochemical (tissue construction cost, CC) and morphological traits (biomass partitioning and leaf mass per unit area, LMA) to the cost associated with leaf area renewal (construction cost of the leafy shoot per unit leaf area, shoot $\mathrm{CC}_{\mathrm{A}}$ ) was studied in saplings of Acer platanoides L. and Fraxinus excelsior L. growing in a natural light gradient below forest canopy. Decrease in LMA with shade and change in biomass partitioning from stems towards leaves and petioles accounted for the strong decrease in mass per unit area of the leafy shoot (SMA) with shade and for most of the plasticity of shoot $\mathrm{CC}_{\mathrm{A}}$ in both species. In addition, a decrease in leaf CC in A. platanoides also contributed to the overall decrease of shoot $\mathrm{CC}_{\mathrm{A}}$ with shade in this species. Leaf $\mathrm{CC}$ was positively correlated with LMA in $F$. excelsior, positively correlated with both LMA and epidermal absorbance of UV ( $\left.\mathrm{A}_{\mathrm{UV}}\right)$ in A. platanoides. Leaf CC was negatively correlated with ash content in both species. The strong negative correlation between $\mathrm{A}_{\mathrm{UV}}$ and nitrogen content might have damped variations in leaf CC in F. excelsior.
\end{abstract}

Acer platanoides L. / Fraxinus excelsior L. / construction cost / shade tolerance / forest regeneration

Résumé - Variations du coût de construction associées au renouvellement de la surface foliaire chez de jeunes plants de deux espèces sympatriques de forêt tempérée (Acer platanoides L. et Fraxinus excelsior L.) le long d'un gradient de lumière. Le renouvellement des feuilles et des structures nécessaires à leur maintien (l'ensemble correspondant à la tige feuillée) représente chaque année un coût pour les plants. La contribution de la composition biochimique (coût de construction des tissus, CC) et des caractéristiques morphologiques (répartition de la biomasse, masse des feuilles par unité de surface, LMA) aux changements du coût associé à l'étalement des feuilles (coût de construction de la tige feuillée, par unité de surface foliaire, $\mathrm{CC}_{\mathrm{A}}$ ) a été étudiée chez de jeunes plants de Acer platanoides L. et Fraxinus excelsior L. croissant dans un gradient naturel de lumière sous un couvert forestier. Une diminution de LMA avec l'ombrage et des modifications de répartition de biomasse au profit des feuilles et des pétioles et au détriment de la tige expliquent la forte diminution de la masse de la tige feuillée de l'année par unité de surface foliaire (SMA), et l'essentiel de la plasticité observée pour $\mathrm{CC}_{\mathrm{A}}$ de la tige feuillée chez les deux espèces. En plus, une diminution du coût de construction des feuilles chez A. platanoides contribue également à la diminution de $\mathrm{CC}_{\mathrm{A}}$ de la tige feuillée avec l'ombrage chez cette espèce. Le coût de construction des feuilles est positivement corrélé à LMA chez F. excelsior, positivement corrélé à LMA et à l'absorbance de l'épiderme dans l'UV ( $\left.\mathrm{A}_{\mathrm{UV}}\right)$ chez A. platanoides. CC des feuilles est négativement corrélé au contenu en cendre chez les deux espèces. La forte corrélation négative entre $\mathrm{A}_{\mathrm{UV}}$ et le contenu en azote pourrait tamponner les variations de CC des feuilles chez F. excelsior.

Acer platanoides L. / Fraxinus excelsior L. / coût de construction / tolérance à l'ombrage / régénération forestière

\section{INTRODUCTION}

Forest canopy constitutes a complex spatial arrangement of foliage and branches, which results in low and variable light penetration down to the forest floor. Light is one of the most limiting resources for forest understorey [4, 25, 29]. Shade limits severely growth and survival of tree saplings, but among species, there is a large inter-specific variability in the degree of tolerance to shade. The ability of trees to acclimate to shade is important for understanding dynamics of forest succession and determining the fate of juvenile trees during natural regeneration.

One of the components of shade tolerance resides in the ability of saplings to maintain a positive carbon balance by optimising carbon gain under low light environments (increasing light interception and photosynthesis) and by minimising respiratory carbon loss $[14,25]$. Leaves display a large plasticity in response to shade characterised by many structural and physiological changes. Especially, the decrease in leaf mass per unit area (LMA) is thought to account for lower nitrogen content

\footnotetext{
* Corresponding author: Daniel.Epron@ scbiol.uhp-nancy.fr
} 
per unit leaf area and lower photosynthetic capacity, but also for lower rate of respiration that would allow higher net $\mathrm{CO}_{2}$ assimilation rates at low irradiance [5].

Whole plant carbon balance depends not only on the photosynthetic capacity of individual leaves, but also on their ability of intercepting light energy, on the energetic costs of producing and maintaining their assimilatory area as well as their nonphotosynthetic organs, and on the pattern of resource allocation among these organs $[14,25]$. Light interception depends on leaf area expansion and branch extension and the setting up of a new leafy shoot represents an annual energy investment for temperate saplings [19]. Leaves often exhibit high construction cost because of their high protein contents associated to photosynthesis $[33,39]$ and their yearly renewal also requires more or less lignified, i.e. more or less expensive organs, like rachis, petioles and stems that constitute the current year shoot [19, 38]. The ability of saplings to reduce this energetic requirement would therefore contribute to their overall shade tolerance.

The objective of this study was to gain a better understanding of the influence of the relative irradiance on the construction cost of leaves and of the different structures that are required for leaf area renewal. Construction cost was defined as the amount of glucose required to provide carbon skeletons, reductants and ATP for synthesizing the organic compounds in a tissue via standard biochemical pathways $[9,44]$. It can be accurately estimated by determining ash and carbon content of plant materials assuming that expensive compounds are more reduced than cheaper ones, and that the reduction state of different compounds is reflected by their carbon content [20, 22, $30,41]$. Cost associated to leaf area renewal was expressed on a per unit leaf area basis. We further investigate whether variations in costs associated to leaf area renewal were due to changes in biochemical composition (changes in tissue construction cost per unit mass) or to modifications in leaf morphology (leaf mass per unit area, LMA) or in biomass allocation between leaves (or leaflets) and supporting structures (rachis, petioles and stems). The study was done on saplings of two cooccurring deciduous temperate tree species Fraxinus excelsior L. and Acer platanoides L. Both were post pioneer species, rated as intermediate in shade tolerance [35] but $A$. platanoides has simple leaves and plagiotropic lateral axes whereas F. excelsior has compound leaves and orthotropic lateral axes.

\section{MATERIALS AND METHODS}

\subsection{Site description}

Sampled saplings were growing in a naturally regenerated stand (Graoully Forest, Moselle, France, $49^{\circ} 05^{\prime}$ N, 6 $6^{\circ} 02^{\prime}$ E, 300 m elevation). The overstorey is dominated by Acer pseudoplatanus L. and Fagus sylvatica L. In addition to these two species, understorey vegetation consisted of saplings of Sorbus torminalis L.; Sorbus aria L.; Acer campestre L.; Acer platanoides L.; Ulmus glabra; Fraxinus excelsior L. and Tilia cordata. Monthly average for air temperature ranged between $1.6^{\circ} \mathrm{C}$ in January to $18.7^{\circ} \mathrm{C}$ in July and total annual rainfall was $745 \mathrm{~mm}$ (data from Météo France, Metz-Augny, 19462001 period).

\subsection{Estimation of irradiance conditions}

Hemispherical photographs were taken above each sapling with a digital camera (Coolpix 4500, Nikon, Japan) equipped with a fisheye converter (FC-E8, Nikon). The camera was mounted with the lens facing sky, aligned with magnetic north and levelled. Photographs were taken in early morning or late afternoon under condition of diffuse radiation. The hemispheric photographs (3.9 million pixels) were analysed using Gap Light Analyser software (GLA V2.0, Institute of Ecosystem Studies, New York, USA, [7, 12]). The threshold for calculating canopy openness was manually fixed using pixel histograms (lowest frequency value) and visually checked. Potential diffuse (standard overcast) and direct photosynthetic active radiations that are transmitted through the canopy above each sapling were calculated from canopy openness and expressed relative to those above the canopy ( $\mathrm{T}_{\mathrm{dif}}$ and $\mathrm{T}_{\text {dir }}$ respectively). Sky regions were defined from 8 azimuth classes and 20 zenith classes and the solar time step was set to 2 min. Global Site Factor $\left(\mathrm{GSF}=\left(\mathrm{T}_{\mathrm{dif}}+\mathrm{T}_{\mathrm{dir}}\right) / 2\right)$, was calculated assuming an equal proportion of diffuse and direct radiation above the canopy $[1,6,11]$, GSF values were averaged over a period starting in May 1 st and ending in August 31th.

\subsection{Sampling and analysis}

Thirty saplings of Acer platanoides L. and 26 saplings of Fraxinus excelsior L. were sampled in the stand in a large range of light environments in August 2003. The height of sampled saplings was restricted to a range of 0.5 and $1.0 \mathrm{~m}$ to limit ontogenic influences on measured parameters.

The current year shoot of each sapling was harvested and stored in an icebox and transferred into a fridge $\left(4^{\circ} \mathrm{C}\right)$ every evening. Shoots were divided into stems, petioles (or rachis) and leaves (or leaflets). Leaf area was measured with a leaf area meter (LI-3000A, Li Cor, Nebraska, USA).

A dual excitation fluorimeter (Dualex ${ }^{\circledR}$ Dual Excitation, prototype CNRS-LURE, France) was used for the non-destructive assessment of phenolics present in leaf epidermis $[8,15]$. Briefly, the measurement of leaf epidermal Absorbance of UV light $\left(\mathrm{A}_{\mathrm{uV}}\right)$ is based on the screening effect of the epidermis that absorbs a part of the incident UV light and therefore decreases the amount of available light for chlorophyll fluorescence excitation. An incident red light is used as reference for chlorophyll fluorescence as the leaf epidermis is almost transparent in this spectral region. The leaf is alternatively illuminated by UV $(375 \mathrm{~nm})$ and red $(655 \mathrm{~nm})$ diodes at a modulation frequency of $1 \mathrm{kHz}$. Epidermal transmittance of UV was computed from the ratio in diode intensities when both light sources led to the same chlorophyll fluorescence intensity and, absorbance was defined as the base-10 logarithm of the transmittance reciprocal [15]. Absorbance values were recorded on both adaxial and abaxial sides of the leaf and further added for a given leaf. An average value of 10 measurements obtained on a sub-sample of leaves was calculated for each plant $\left(\mathrm{A}_{U V}\right)$. A tight correlation was found between $\mathrm{A}_{\mathrm{UV}}$ and the absorbance of a methanolic extract of leaves of the two studied species $\left(r^{2}=0.85, n=40\right.$, $p<0.0001)$, as previously reported for wheat $[8,15]$.

Leaf (or leaflet) dry mass was estimated after lyophilisation. Dry mass of other organs (twigs, petioles, rachis) was estimated after oven drying the samples at $60^{\circ} \mathrm{C}$ for at least $48 \mathrm{~h}$. All samples were ground to a fine powder and stored dry until analysis. Total carbon and nitrogen were determined with an elemental microanalyser (NCS 2500, Thermoquest, Italy). Ash contents were determined by weighting the remaining mass after combustion in a muffle furnace at $550^{\circ} \mathrm{C}$ for $6 \mathrm{~h}$.

\subsection{Construction costs}

Construction cost $\left(\mathrm{CC}, \mathrm{g}\right.$ glucose $\mathrm{g}^{-1}$ ) was calculated from carbon $\left(\mathrm{C}, \mathrm{g} \mathrm{g}^{-1}\right)$ and ash $\left(\mathrm{A}, \mathrm{g} \mathrm{g}^{-1}\right)$ contents assuming that the reduction state of organic compounds is related to their carbon content [41]:

$$
\mathrm{CC}=[-1.041+5.077 \mathrm{C} /(1-\mathrm{A})](1-\mathrm{A}) \text {. }
$$


For 29 samples covering the whole range of construction cost values, the ash free heat of combustion $\left(\mathrm{Hc}, \mathrm{kJ} \mathrm{g}^{-1}\right.$ ) was measured in a bomb calorimeter (1425, semi micro bomb calorimeter, Parr, Illinois, USA) and further used to calculate $\mathrm{CC}$ following the procedure of Williams et al. [44]. Construction costs estimated from carbon content were well correlated with those estimated from heat of combustion $\left(r^{2}=0.89\right.$, $n=29, p<0.0001$, data not shown).

Nitrogen content was not taken into account for the calculation of $\mathrm{CC}$, assuming that ammonium is the main nitrogen source. An additional cost for nitrate reduction should be added when nitrate is thought to be the main nitrogen source and when its reduction occurrs in nonphotosynthetic tissues [30]. The reported values would underestimate true CC if nitrate reduction occurs in roots in these species. Similar N isotope signatures in leaves of both species support the hypothesis that both species are using the same source of nitrogen, and that $\mathrm{CC}$ values were similarly biased for both species (unpublished results).

\subsection{Calculations and statistical analysis}

Leaf mass per unit area (LMA, $\mathrm{g} \mathrm{m}^{-2}$ ) was calculated as the ratio between the leaf dry mass and leaf area of all leaves held by the current year shoot. Shoot mass per unit leaf area (SMA, $\mathrm{g} \mathrm{m}^{-2}$ ) was calculated as the ratio between the dry mass of the current year shoot (leaves, petioles and stems) and the leaf area of this shoot. Leaf construction cost per unit leaf area (leaf $\mathrm{CC}_{\mathrm{A}}, \mathrm{g}$ glucose $\mathrm{m}^{-2}$ ) was the product of leaf CC and LMA. The construction cost of the leafy shoot per unit dry mass (shoot $\mathrm{CC}, \mathrm{g}$ glucose $\mathrm{g}^{-1}$ ) was calculated by summing, for all organs, the products of their construction cost (CC) and their relative contribution to the biomass of the leafy shoot $\left(\mathrm{RM}, \mathrm{g} \mathrm{g}^{-1}\right)$. Construction cost of the leafy shoot per unit leaf area (shoot $\mathrm{CC}_{\mathrm{A}}$, g glucose $\mathrm{m}^{-2}$ ) was the product of leaf CC and LMA.

Analyses of covariance (ANCOVA) were performed to test for main effects and interaction of species and light (GSF) for all measured variables. If the effect of GSF was significant for a given variable $(p<0.05)$, linear regressions were computed and showed on figures.

Table I. Analyses of covariance of the effects of species and global site factor (GSF) on leaf (or leaflets), petiole (or rachis), stem and the whole leafy shoot construction costs on a per unit mass basis (CC) and relative contributions of leaf, petiole and stem to the biomass of current year shoot, leaf mass per unit area (LMA), shoot mass per unit area (SMA), leaf and leafy shoot construction costs on a per unit area basis $\left(\mathrm{CC}_{\mathrm{A}}\right)$, leaf nitrogen content $(\mathrm{N})$, leaf ash content and Dualex derived $\mathrm{UV}$ absorbance $\left(\mathrm{A}_{\mathrm{UV}}\right)$. F ratio followed by $*$, ** or *** are significantly higher than unity at $0.05,0.01$ and 0.001 respectively.

\begin{tabular}{lccc}
\hline & Species & GSF & Sp x GSF \\
\hline Leaf CC & $28.0 * * *$ & $39.4 * * *$ & $5.8 *$ \\
LMA & 0.38 & $100.3 * * *$ & $6.9 *$ \\
Leaf CC & 0.0 & $112.3 * * *$ & 3.9 \\
Petiole CC & $11.9 * *$ & 1.3 & 3.8 \\
Stem CC & 0.2 & 1.1 & $8.0 * *$ \\
Relative leaf mass & $4.1 *$ & $4.9 *$ & 0.1 \\
Relative petiole mass & 1.2 & $12.2 * *$ & 0.3 \\
Relative stem mass & 3.0 & $12.2^{* * *}$ & 0.2 \\
Shoot CC & $15.7 * * *$ & $40.4 * * *$ & $7.4 * *$ \\
SMA & 1.6 & $73.9 * * *$ & 3.9 \\
Shoot CC & 1.1 & $83.3 * * *$ & 2.5 \\
Leaf ash & $119.6 * * *$ & $4.1 *$ & 0.2 \\
Leaf $\mathrm{N}$ & $13.5 * *$ & $9.0 * *$ & $6.6 *$ \\
A & $7.1 *$ & $41.0 * * *$ & 1.0 \\
\hline
\end{tabular}
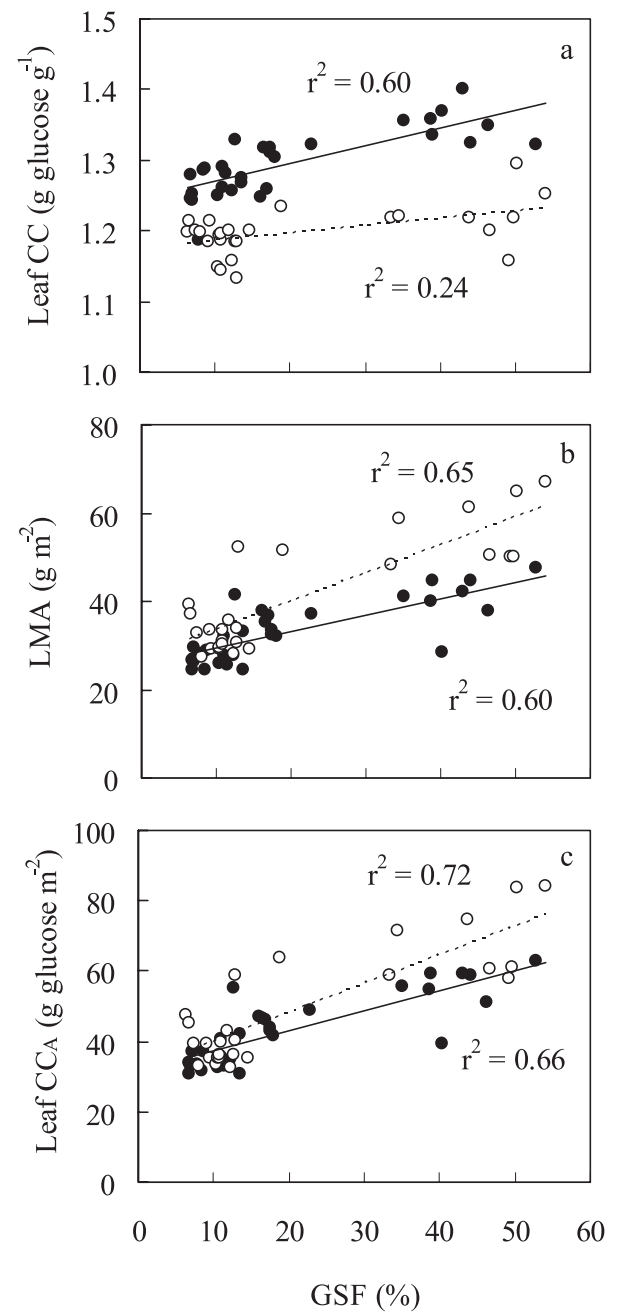

Figure 1. Relationships between irradiance (Global site factor, GSF) and leaf construction cost per unit leaf mass $(\mathrm{CC}$, a), leaf mass per unit area (LMA, b) and leaf construction cost per unit leaf area $\left(\mathrm{CC}_{\mathrm{A}}\right.$, c) for A. platanoides (closed symbols) and $F$. excelsior (open symbols). Determination coefficients $\left(r^{2}\right)$ and linear regression lines (full line for A. platanoides and dotted line for $F$. excelsior) are given when significant $(p<0.05)$.

Pearson correlation coefficients between leaf traits were calculated. All statistical analyses were performed using Stat View 5.1 (SAS Institute Inc, North Carolina, USA).

\section{RESULTS}

\subsection{Leaf construction cost}

Saplings of both species were sampled within the same light gradient, with GSF values ranging between $6 \%$ and $52 \%$. Unfortunately, intermediate values of GSF (20-40\%) were underrepresented for both species.

Leaf construction costs on a per unit mass basis were higher in A. platanoides than in $F$. excelsior (1.30 versus $1.20 \mathrm{~g}$ glucose $\mathrm{g}^{-1}$ respectively for mean values, $p<0.001$; Tab. I), and decreased with increasing shade ( $p<0.001$; Fig 1a), especially in A. platanoides, and to a lesser extent in F. excelsior. 

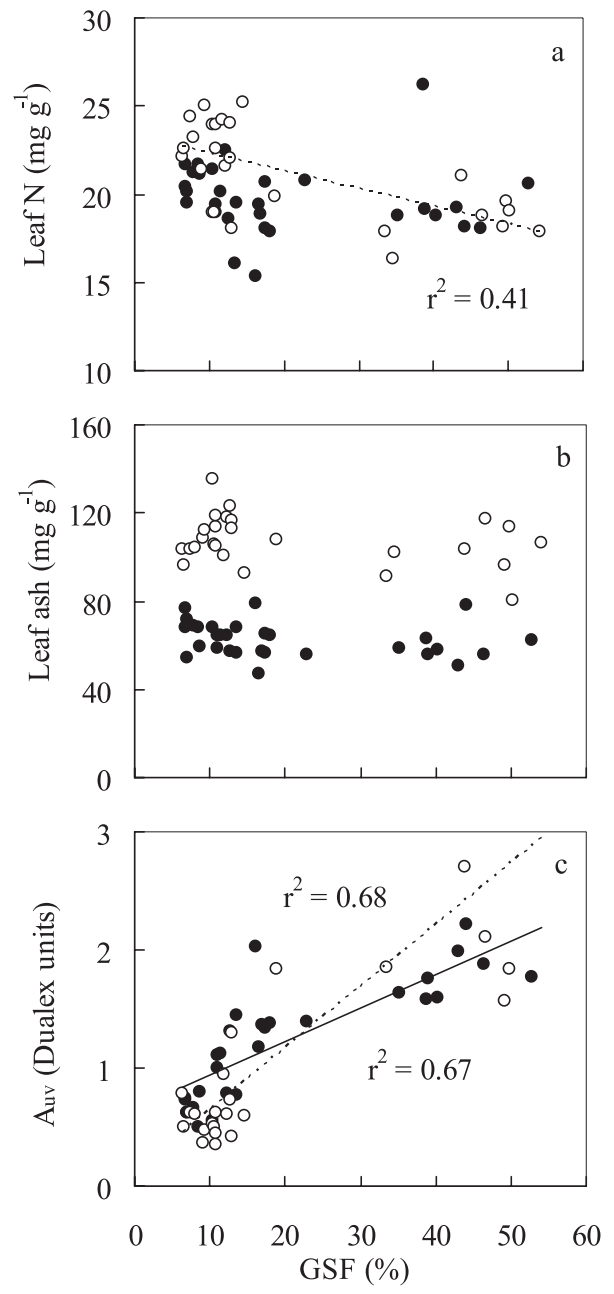

Figure 2. Relationships between irradiance (Global site factor, GSF) and leaf nitrogen content $(\mathrm{N}, \mathrm{a})$, leaf ash content (b) and Dualex derived UV absorbance $\left(\mathrm{A}_{\mathrm{UV}}, \mathrm{c}\right)$ for A. platanoides (closed symbols) and F. excelsior (open symbols). Determination coefficients $\left(r^{2}\right)$ and linear regression lines (full line for A. platanoides and dotted line for $F$. excelsior $)$ are given when significant $(p<0.05)$.

Leaf mass per unit area (LMA) decreased significantly with increasing shade ( $p<0.001$; Fig. 1b) especially in F. excelsior. Therefore, expressed on a per unit leaf area basis, leaf construction costs (leaf $\mathrm{CC}_{\mathrm{A}}, \mathrm{g}$ glucose $\mathrm{m}^{-2}$ ) decreased markedly with increasing shade in both species $\left(p<0.001\right.$; Fig. 1c). Leaf $\mathrm{CC}_{\mathrm{A}}$ were almost similar in the two species. The effect of light on leaf $\mathrm{CC}_{\mathrm{A}}$ was more pronounced than on leaf $\mathrm{CC}$ due to the effect of shade on LMA.

\subsection{Leaf composition}

Leaf nitrogen content $(\mathrm{N})$ ranged between 15 to $30 \mathrm{mg} \mathrm{g}^{-1}$ in both species. For $F$. excelsior, $\mathrm{N}$ increased with increasing shade, whereas it remained almost constant in A. platanoides (Fig. 2a). Leaf ash content slightly decreased with decreasing light in both species ( $p=0.048$; Fig. 2b). In contrast, the Dualex-derived UV absorbance of leaf epidermis ( $A_{U V}$ ) of
Table II. Pearson's correlation coefficients of leaf construction cost (CC), leaf mass per unit area (LMA), leaf nitrogen content (N), leaf ash content and Dualex derived UV absorbance ( $\mathrm{A}_{\mathrm{UV}}$ ) for saplings of Acer platanoides (left) and Fraxinus excelsior (right). Correlation coefficients $(r)$ followed by $* * *$ or $* * *$ are significantly higher than zero at $0.05,0.01$ and 0.001 respectively.

\begin{tabular}{lllll}
\hline \multicolumn{5}{c}{ Fraxinus excelsior } \\
\hline Leaf CC & $+0.55^{* *}$ & +0.34 & -0.03 & $-0.60^{* * *}$ \\
$+0.59^{* * *}$ & LMA & $+0.70^{* * *}$ & $-0.71^{* * *}$ & $-0.40^{*}$ \\
$+0.59^{* * *}$ & $+0.51^{* *}$ & $\mathbf{A}_{\mathbf{U V}}$ & $-0.72^{* * *}$ & -0.25 \\
-0.03 & -0.21 & $-0.51^{* *}$ & $\mathbf{N}$ & -0.02 \\
$-0.45^{*}$ & -0.30 & 0.08 & -0.04 & $\mathbf{A s h}$ \\
\hline \multicolumn{5}{c}{ Acer platanoides } \\
\hline
\end{tabular}
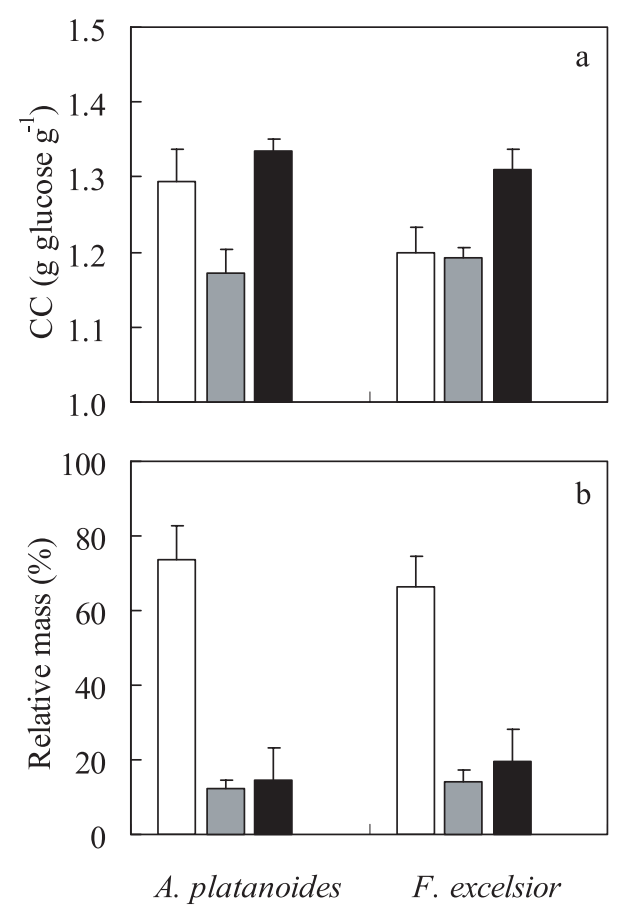

Figure 3. Mean construction cost per unit mass $(\mathrm{CC}$, a) and relative contribution to shoot biomass (b) of leaves or leaflets (open bars), petioles or rachis (hatched bars) and stems (solid bars) for A. platanoides $(n=30)$ and F. excelsior $(n=26)$. Vertical bars represent standard deviation $( \pm \mathrm{SD})$.

both species significantly decreased with increasing shade $(p<0.001$; Fig. 2c).

There was no significant correlation between leaf $\mathrm{CC}$ and $\mathrm{N}$ content (Tab. II). Leaf CC was positively correlated with LMA in F. excelsior $(p<0.001)$, and with both LMA and $\mathrm{A}_{\mathrm{UV}}$ in $A$. platanoides $(p<0.001)$. In contrast, leaf CC was negatively correlated with leaf ash content in both species.

\subsection{Shoot construction cost}

$\mathrm{CC}$ of organs of the leafy shoot other than leaves or leaflets (petioles, rachis, and stems) remained fairly constant with 

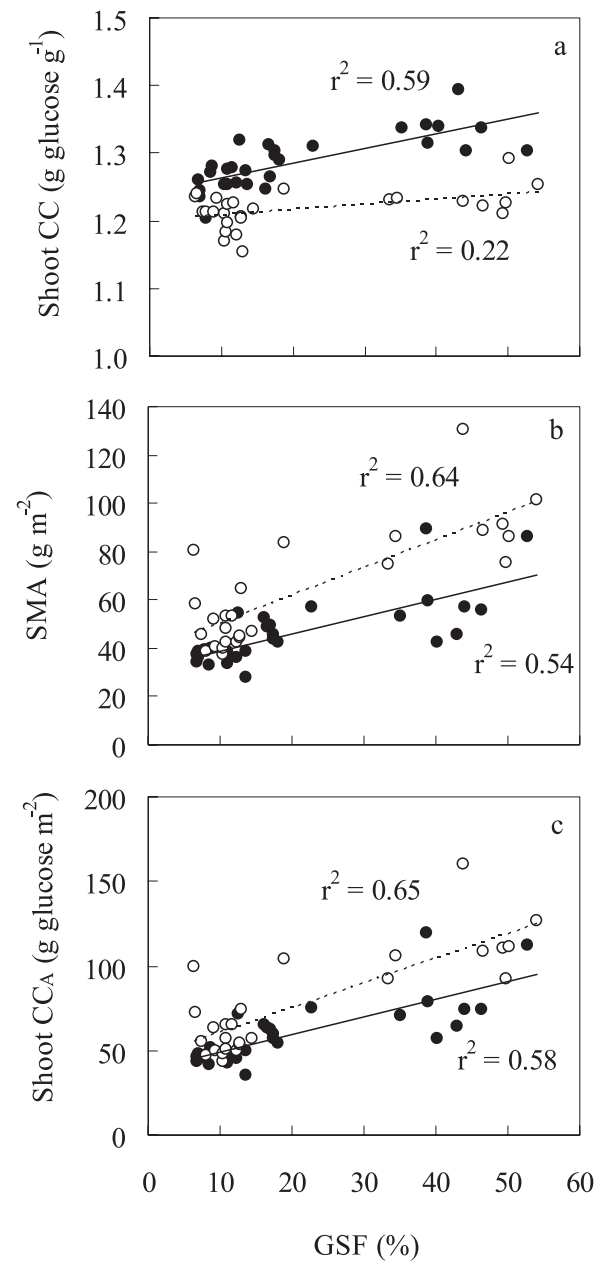

Figure 4. Relationships between irradiance (Global site factor, GSF) and construction cost of the leafy shoot per unit mass (CC, a), shoot mass per unit area (SMA, b) and construction cost of the leafy shoot per unit of leaf area $\left(\mathrm{CC}_{\mathrm{A}}, \mathrm{c}\right)$ for A. platanoides (closed symbols) and $F$. excelsior (open symbols). Determination coefficients $\left(r^{2}\right)$ and linear regression lines (full line for A. platanoides and dotted line for $F$. excelsior $)$ are given when significant $(p<0.05)$.

increasing shade, and were almost similar for the two species (Fig. 3a). Stems exhibited higher values of construction cost $\left(1.31 \mathrm{~g}\right.$ glucose $\left.^{-1}\right)$ than leaflets (1.20) and rachis (1.19) in F. excelsior. Construction costs of stems (1.33) were in the same range of values than those of leaves (1.29) while petioles had lower CC in A. platanoides (1.17).

Leaves accounted for $74 \%$ of the biomass of the current year shoot in A. platanoides and $66 \%$ in F. excelsior. Stems and petioles accounted for respectively $14 \%$ and $12 \%$ in A. platanoides and $20 \%$ and $14 \%$ in F. excelsior (Fig 3b). There was a slight increase in relative leaf and petiole biomass with increasing shade $(p<0.05)$ while relative stem biomass decreased ( $p<0.001$, data not shown). Shoot CC were slightly higher for A. platanoides than for $F$. excelsior ( $p<0.001$; Fig. $4 a$ ), and decreased significantly with shade, particularly in A. platanoides and to a lesser extent in F. excelsior.
SMA decreased with shade $(p<0.001 ;$ Fig. $4 b)$. Therefore, shoot $\mathrm{CC}_{\mathrm{A}}$ decreased with increasing shade $(p<0.001$; Fig. $4 c$ ). Shoot $\mathrm{CC}_{\mathrm{A}}$ was higher in F. excelsior than in A. platanoides (on average $6 \%, p<0.001$ ).

\section{DISCUSSION}

\subsection{Construction cost associated to leaf area renewal}

The cost which is associated to leaf area renewal can be defined as the amount of glucose equivalent per unit leaf area that is required for growing a new leafy shoot ( $\operatorname{shoot} \mathrm{CC}_{\mathrm{A}}$ ) that will enable light interception and photosynthetic assimilation. The substantial decrease in shoot $\mathrm{CC}_{\mathrm{A}}$ that was observed with increasing shade in A. platanoides and $F$. excelsior may be ascribed to either morphological changes (decrease in the mass of current year shoot per unit leaf area) or biochemical changes (decrease in organ construction costs).

Low LMA is thought to contribute to shade tolerance because it allows a larger leaf area and a greater light interception for a given biomass investment in leaves [40]. Indeed, low LMA in shaded saplings or in shaded leaves within tree crowns has been well documented in many species [10, 21, 28, 36, 37], and it accounted for lower SMA for the two temperate species studied here. In addition, a shift in aboveground production toward leaves and petioles in shaded saplings was also observed, as already reported for saplings of tropical and temperate species [17-19, 34]. A decrease in relative petiole mass with increasing light was already reported for F. excelsior [27] and was also observed in A. platanoides. These shifts could result either from ontogenic changes ("apparent plasticity" resulting from difference in the size reached by individuals in the different light environments [19]), or from an optimisation of biomass allocation ("true plasticity", independent from size mediated effects). Whatever, changes in LMA and in biomass allocation to leaves together account for the reduction of the cost associated to leaf area renewal in A. platanoides and F. excelsior. As soon as leaflets (in F. excelsior) and petioles or rachis (in both species) had lower construction costs than stems, the observed shift in biomass allocation from shoot to leaves and petioles also accounts for the reduction of the construction cost of the shoot. Changes in both leaf structural traits and in allocation towards low-cost tissue decreased the cost associated to leaf area renewal. Any change in chemical composition of organs will reinforce or counterbalance this effect.

\subsection{Tissue construction costs}

Leaf construction cost of the two studied species was in the range of published values for leaves of woody species from different ecosystems [9, 24, 33, 39]. Leaf CC were higher in A. platanoides than in $F$. excelsior. High mineral contents, as revealed by high ash content in leaves of $F$. excelsior, have a null direct cost. It probably explains the low construction cost of leaflets for this species. Similar results have been obtained on tomato leaves [13].

Petioles are cheaper than leaves as already reported [26] while woody stems are more expensive because of their higher lignin content. Assuming $\mathrm{NO}_{3}^{-}$nutrition rather than $\mathrm{NH}_{4}{ }^{+}$ 
nutrition, and $\mathrm{NO}_{3}{ }^{-}$reduction in non photosynthetic organs, would have yielded higher construction costs for all organs, and especially for leaves (8\% higher values). Leaves would then display higher construction costs than stems [30,33]. However, it would not have changed the overall tendency reported here.

Leaf CC exhibited biochemical plasticity with GSF in A. platanoides while it was less pronounced in $F$. excelsior. There is no general rule on the impact of light availability on leaf construction cost. Leaf CC were $10 \%$ to $20 \%$ higher in gaps than in the understorey in some tropical Piper species [43]. On the contrary, leaves of Alocasia macrorrhiza were slightly more expensive (5\%) in low light than in high light [38]. Changes in LMA with light often results from changes in both thickness and tissue density [28]. The positive correlation between LMA and leaf CC was probably related to an increased amount of lignified cell walls in light due to changes in the relative contribution of palisade and spongy parenchyma, or to a decrease in cell size [3]. In addition, epidermis thickness (lignified cell walls) and cuticle thickness (lipid-rich compounds) are frequently increased with increasing LMA along a light gradient $[2,40]$. The positive correlation between LMA and leaf $\mathrm{CC}$ found here is in agreement with a lower investment in structural compounds in shaded leaves.

The Dualex-derived UV absorbance $\left(\mathrm{A}_{U V}\right)$ increased with irradiance for both species. However, $A_{U V}$ was not correlated to leaf CC in F. excelsior. Net balance of biochemical changes accounts for variation in construction cost. Different chemical compositions might result in similar $\mathrm{CC}$, and thus, $\mathrm{CC}$ might be almost insensitive to environmental changes even if the biochemical composition of an organ is altered [9, 23, 33]. Leaves with high protein contents often exhibited high mineral contents when compared among species [31, 32, 42]. In this study, there was no relation between nitrogen and ash content, but leaf $\mathrm{CC}$ was negatively related to leaf ash content in both species. The low level of variation of leaf CC in F. excelsior across light gradients is probably related to the strong negative correlation between $\mathrm{A}_{\mathrm{UV}}$ and nitrogen content $(\mathrm{N})$. $\mathrm{A}_{\mathrm{UV}}$ and $\mathrm{N}$ are respectively indicative of phenolic and protein contents that are both expensive compounds. This negative correlation between two expensive compounds might have damped variations in construction cost [9].

$\mathrm{N}$ increased in leaves of $F$. excelsior with shade whereas it remained almost constant in leaves of $A$. platanoides. Increased leaf $\mathrm{N}$ with shade could enhance photosynthetic capacity (per unit leaf mass) but could in turn increase construction costs (and maintenance costs) of leaves, lowering the benefice in terms of carbon balance $[16,36]$. The results would be even more detrimental if $\mathrm{NO}_{3}{ }^{-}$was the main source of nitrogen. In addition, high $\mathrm{N}$ is thought to increase vulnerability to herbivory, and then, to reduce leaf lifespan and integrated carbon gain [45].

\section{CONCLUSIONS}

Lower cost associated to leaf area renewal in saplings growing in deep shade counteracts the lower photosynthetic carbon assimilation per unit leaf area in low light conditions. Construction costs associated to leaf area renewal are more affected by shade-induced changes in leaf structure than in tissue chemistry. Lower LMA and, to a lesser extent, larger allocation to leaves in deep shade than in light shade are morphological plastic responses that reduce shoot $\mathrm{CC}_{\mathrm{A}}$. In addition, a decrease of leaf CC with shade was observed in A. platanoides (biochemical plasticity). Ontogenic variations in biochemical composition of plant tissues that induced changes in construction cost have been reported $[13,24]$. The cost associated to secondary growth of stem tissues during the following years will have to be considered, especially when changes in light availability occur.

Acknowledgements: The authors thank Catherine Collet and Alexandre Piboule for the access to the experimental site, Jacqueline Marchand and Marie-Laure Toussaint for their help in elemental analysis, Claude Brechet for ${ }^{15} \mathrm{~N}$ analysis, Pierre Montpied for his help with hemispheric photography, Erwin Dreyer, Badr Alaoui Sossé, Geneviève Chiapusio and two anonymous reviewers for valuable suggestions and helpful comments. This work was partially supported by the "Réseau de l'Écophysiologie de l'Arbre" (INRA, France).

\section{REFERENCES}

[1] Anderson M.C., Studies of the woodland light climate, I, The photographic computation of light conditions, J. Ecol. 52 (1964) 27-41.

[2] Ashton P.M.S., Berlyn G.P., A comparison of leaf physiology and anatomy of Quercus (section Erythrobalanus Fagaceae) species in different light environments, Am. J. Bot. 81 (1994) 589-597.

[3] Baruch Z., Goldstein G., Leaf construction costs, nutrient concentration, and net $\mathrm{CO}_{2}$ assimilation of native and invasive species in Hawaii, Oecologia 121 (1999) 183-192.

[4] Bazzaz F.A., Wayne P.M., Coping with environmental heterogeneity: the physiological ecology of tree seedling regeneration across the gap-understorey continuum, in: Caldwell M.M., Pearcy R.W. (Eds.), Exploitation of environmental heterogeneity by plants, ecophysiological processes above and below ground: Physiological ecology, Academic Press, San Diego, 1994, pp. 349-390.

[5] Boardman N.K., Comparative photosynthesis of sun and shade plants, Ann. Rev. Plant Physiol. 28 (1977) 355-377.

[6] Canham C.D., Denslow J.S., Platt W.J., Runkle J.R., Spies T.A., White P.S., Light regimes beneath closed canopies and tree fallgaps in temperate and tropical forest, Can. J. For. Res. 20 (1990) 620-631.

[7] Canham C.D., Software for calculation of light transmission through forest canopies using colour fisheye photography, Institute for Ecosystem Studies, Millbrook, NY, 1995.

[8] Cartelat A., Cerovic Z.G., Goulas Y., Meyer S., Lelarge C., Prioul J.L., Barbottin A., Jeuffroy M.H., Gate P., Agati G., Moya I., Optically assessed contents of leaf polyphenolics and chlorophyll as indicators of nitrogen deficiency in wheat (Triticum aestivum L.), Field Crops Res. 95 (2005) 35-49.

[9] Chapin F.S.III., The cost of plant structures: evaluation of concepts and currencies, Am. Nat. 133 (1989) 1-19.

[10] Ellsworth D.S., Reich P.B., Canopy structure and vertical patterns of photosynthesis and related leaf traits in a deciduous forest, Oecologia 96 (1993) 169-178.

[11] Frazer G.W., Fournier R.A., Trofymow J.A., Hall R.J., A comparison of digital and film fisheye photography for analysis of forest canopy structure and gap light transmission, Agr. Forest. Meteor. 109 (2001) 249-263.

[12] Frazer, G.W., Canham, C.D., Lertzman, K.P., Gap Light Analyzer (GLA), Version 2.0: Imaging software to extract canopy structure 
and gap light transmission indices from true-colour fisheye photographs, users manual and program documentation, Simon Fraser University, Burnaby, British Columbia, and the Institute of Ecosystem Studies, Millbrook, New York, 1999.

[13] Gary C., Bertin N., Lebot J., High mineral contents explain the low construction cost of leaves, stem, and fruits of tomato plants, J. Exp. Bot. 49 (1998) 49-57.

[14] Givnish T.J., Adaptation to sun and shade: a whole plant perspective, Aust. J. Plant Physiol. 15 (1988) 63-92.

[15] Goulas Y., Cerovic Z.G., Cartelet A., Moya I., Dualex: a new instrument for field measurements of epidermal UV absorbance by chlorophyll fluorescence, Appl. Opt. 43 (2004) 4488-4496.

[16] Griffin K.I., Thomas R.B., Strain B.R., Effects of nutrient supply and elevated carbon dioxide on construction cost in leaves of Pinus taeda seedlings, Oecologia 95 (1993) 575-580.

[17] King D.A., Correlations between biomass allocation, relative growth rate and light environment in tropical forest saplings, Funct. Ecol. 5 (1991) 485-492.

[18] King D.A., Influence of light level on the growth and morphology of saplings in a Panamanian forest, Am. J. Bot. 81 (1994) 948-957.

[19] King D.A., Allocation of above-ground growth is related to light in temperate deciduous saplings, Funct. Ecol. 17 (2001) 482-488.

[20] Laffite H.R., Loomis R.S., Calculation of growth yield, growth respiration, and heat content of grain sorghum from elemental and proximal analysis, Ann. Bot. 62 (1988) 353-361.

[21] Le Roux X., Sinoquet H., Vandame M., Spatial distribution of leaf weight per area and leaf nitrogen content in relation to local radiation regime within an isolated tree crown, Tree Physiol. 19 (1999) 181-188.

[22] McDermitt D.K., Loomis R.S., Elemental composition of biomass and its relation to energy content, growth efficiency, and growth yield, Ann. Bot. 48 (1981) 275-290.

[23] Martinez F., Lazo Y.O., Fernandez-Galiano R.M., Merino J.A., Chemical composition and construction cost of roots of Mediterranean trees, shrub species and grassland communities. Plant Cell Environ. 25 (2002) 601-608.

[24] Merino J.A., Field C.B., Mooney H.A., Construction and maintenance costs of Mediterranean-climate evergreen and deciduous leaves. II. Biochemical pathway analysis, Oecol. Plant. 5 (1984) 211229.

[25] Messier C., Doucet R., Ruel J.C., Claveau Y., Kelly C., Lechowicz M.J., Functional ecology of advance regeneration in relation to light in Boreal forests, Can. J. For. Res. 29 (1999) 812-823.

[26] Niinemets Ü., Are compound-leaved woody species inherently shade-intolerant? An analysis of species ecological requirements and foliar support costs, Plant Ecol. 134 (1998) 1-11.

[27] Niinemets Ü., Kull O., Biomass investment in leaf lamina versus lamina support in relation to growth irradiance and leaf size in temperate deciduous trees, Tree Physiol. 19 (1999) 349-358.

[28] Niinemets Ü., Valladares F., Ceulemans R., Leaf-level phenotypic variability and plasticity of invasive Rhododendron ponticum and non-invasive Ilex aquifolium co-occuring at two contrasting European sites, Plant Cell Environ. 26 (2003) 941-956.

[29] Pearcy R.W., Sims D.A., Photosynthetic acclimatation to changing light environments: scaling from the leaf to the whole plant, in: Caldwell M.M., Pearcy R.W. (Eds.), Exploitation of environmental heterogeneity by plants, ecophysiological processes above and below ground: Physiological Ecology, Academic press, San Diego, 1994, pp. 145-174.
[30] Poorter H., Construction costs and payback time of biomass: a whole-plant perspective, in: Roy J., Garnier E. (Eds.), A whole plant perspective on carbon-nitrogen interactions, S.P.B Academic Publishing, The Hague, 1994, pp. 111-127.

[31] Poorter H., Bergkotte M., Chemical composition of 24 wild species differing in relative growth rate, Plant Cell Environ. 15 (1992) 2211-2229.

[32] Poorter H., De Jong R., A comparison of specific leaf area, chemical composition and leaf construction costs of field plants from 15 habitats differing in productivity, New Phytol. 143 (1999) 163176.

[33] Poorter H., Villar R., The fate of acquired carbon in plants: chemical composition and construction costs, in: Bazzaz F.A., Grace J. (Eds.), Plant resource allocation, Academic Press, San Diego, 1997, pp. $39-72$.

[34] Poorter L., Light-dependent changes in biomass allocation and their importance for growth of rain forest tree species, Funct. Ecol. 15 (2001) 113-123.

[35] Rameau J.C., Mansion M., Dumé G., Flore forestière française, guide écologique illustré, Tome 1 : Plaines et collines, Institut pour le développement forestier, Paris, 1993.

[36] Reich P.B., Walters M.B., Ellsworth D.S., Vose J., Volin J., Gresham C., Bowman W., Relationships of leaf dark respiration to leaf N, SLA, and life span: a test across biomes and functional groups, Oecologia 114 (1998) 471-482.

[37] Roggy J.C., Nicolini E., Imbert P., Caraglio Y., Bosc A., Heuret P., Links between tree structure and functional leaf traits in the tropical forest tree Dicorynia guianensis Amshoff (Caesalpinaceae), Ann. For. Sci. 62 (2005) 553-564.

[38] Sims D.A., Pearcy R.W., Scaling sun and shade photosynthetic acclimatation of Alocasia macrorrhiza to whole-plant performance. I. Carbon balance and allocation at different daily photon flux densities, Plant Cell Environ. 17 (1994) 881-887.

[39] Sobrado M.A., Cost-benefit relationships in deciduous and evergreen leaves of tropical dry forest species, Funct. Ecol. (1991) 608616.

[40] Valladares F., Skillman J.B., Pearcy R.W., Convergence in light capture efficiencies among tropical forest shade tolerant plants with contrasting crown architectures: a case of morphological compensation, Am. J. Bot. 89 (2002) 1275-1284.

[41] Vertregt N., Penning de Vries F.W.T., A rapid method for determining the efficiency of biosynthesis of plant biomass, J. Theor. Biol. 128 (1987) 109-119.

[42] Villar R., Merino J., Comparison of leaf construction costs of woody species with differing leaf life-spans in contrasting ecosystems, New Phytol. 151 (2001) 213-226.

[43] Williams K., Field C.B., Mooney H.A., Relationships among leaf construction cost, leaf longevity, and light environment in rainforest plants of the Genus Piper, Am. Nat. 133 (1989) 198-211.

[44] Williams K., Percival F., Merino J., Mooney H.A., Estimation of tissue construction cost from heat of combustion and organic nitrogen content, Plant Cell Environ. 10 (1987) 725-734.

[45] Wright I.J, Reich P.B., Westoby M., Ackerly D.D., Baruch Z., Bongers F., Cavender-Bares J., Chapin T., Cornelissen J.H.C., Diemer M., Flexas J., Garnier E., Groom P.K., Gulias J., Hikosaka K., Lamont B.B., Lee T., Lee W., Lusk C., Midgley J.J., Navas M.L., Niinemets U., Oleksyn J., Osada N., Poorter H., Poot P., Prior L., Pyankov V.I., Roumet C., Thomas S.C., Tjoelker M.G., Veneklaas E.J., Villar R., The worldwide leaf economics spectrum, Nature 428 (2004) 821-827. 